Article

\title{
A Trinuclear Oxo-Chromium(III) Complex Containing the Natural Flavonoid Primuletin: Synthesis, Characterization, and Antiradical Properties
}

\author{
Anamaria D. P. Alexiou ${ }^{1, *}$, Carla C. Decandio ${ }^{1}$, Sabrina da N. Almeida ${ }^{1}$, \\ Marcelo J. P. Ferreira ${ }^{2}$, Paulete Romoff ${ }^{1}$ and Reginaldo C. Rocha ${ }^{3}$ \\ 1 Escola de Engenharia, Universidade Presbiteriana Mackenzie, Rua da Consolação 930, São Paulo, \\ SP CEP 01302-000, Brazil; E-Mails: carla.decandio@ufabc.edu.br (C.C.D.); \\ sabrina-nobrega@usp.br (S.N.A.); paulete.romoff@mackenzie.br (P.R.) \\ 2 Departamento de Botânica, Instituto de Biociências, Universidade de São Paulo, Rua do Matão, \\ 277, São Paulo, SP CEP 05508-090, Brazil; E-Mail: marcelopena@ib.usp.br \\ 3 Los Alamos National Laboratory, Los Alamos, NM 87545, USA; E-Mail: rcrocha@lanl.gov \\ * Author to whom correspondence should be addressed; E-Mail: anamaria.alexiou@mackenzie.br; \\ Tel.: +55-11-2114-8145.
}

Academic Editor: Roman Dembinski

Received: 11 March 2015 / Accepted: 1 April 2015 / Published: 10 April 2015

\begin{abstract}
A new trinuclear oxo-centered chromium(III) complex with formula $\left[\mathrm{Cr}_{3} \mathrm{O}\left(\mathrm{CH}_{3} \mathrm{CO}_{2}\right)_{6}(\mathrm{~L})\left(\mathrm{H}_{2} \mathrm{O}\right)_{2}\right](\mathrm{L}=$ 5-hydroxyflavone, known as primuletin) was synthetized and characterized by ESI mass spectrometry, thermogravimetry, and ${ }^{1} \mathrm{H}-\mathrm{NMR}$, UV-Vis, and FTIR spectroscopies. In agreement with the experimental results, DFT calculations indicated that the flavonoid ligand is coordinated to one of the three $\mathrm{Cr}$ (III) centers in an $O, O$-bidentate mode through the 5-hydroxy/4-keto groups. In a comparative study involving the uncoordinated primuletin and its corresponding complex, systematic reactions with the free radical 2,2-diphenyl-1-picrylhydrazyl (DPPH) showed that antiradical activity increases upon complexation.
\end{abstract}

Keywords: antiradical activity; chromium(III) complexes; flavonoids; metal-oxo cluster; primuletin 


\section{Introduction}

Polyphenolic compounds abound in nature and are found in fruits and vegetables, as well as in green and black tea, olive oil, wine and chocolate. The main compounds within this group are the flavonoids, which possess $\mathrm{C}_{6}-\mathrm{C}_{3}-\mathrm{C}_{6}$ units with each $\mathrm{C}_{6}$ representing an aromatic ring. Several reported studies have demonstrated that such compounds show cytoprotective and antioxidant properties [1]. Among the accepted mechanisms to explain the antioxidant activity of polyphenols is the involvement of metal coordination and scavengers of reactive oxygen species produced in living organisms [2]. The hydroxyl groups of flavonoids can bind to metal ions and, as a result, lead to an enhancement of antioxidant properties. Studies with rutin have shown that coordination with copper enhances the ability to scavenge radicals as compared to the free flavonoid [3]. The flavonoids quercetin, galangin, and catechin also have the antioxidant activity increased by coordination with iron(III), aluminum(III), zinc(II), and copper(II) [4]. Although most studies involve coordination with quercetin, other less studied flavonoids have attracted interest. For example, Li et al. showed that complexes formed from $\mathrm{Ni}(\mathrm{II}), \mathrm{Cu}(\mathrm{II})$, and $\mathrm{Zn}(\mathrm{II})$ with a naringenin Schiff base are more active in the suppression of $\mathrm{O}_{2}{ }^{-}$and $\mathrm{HO} \bullet$ radicals [5].

Chromium(III) is an essential metal ion involved in the metabolism of sugar and fats. Chromium-containing nutritional supplements, especially in the form of picolinate (i.e., $\left[\mathrm{Cr}^{\mathrm{III}}\left(\mathrm{pic}_{3}\right)_{3}\right)$, have been used since the 1980 s to improve glucose metabolism, reducing fat and increasing the amount of muscle. Since the use of $\left[\mathrm{Cr}^{\mathrm{III}}\left(\mathrm{pic}_{3}\right]\right.$ at high concentrations can be genotoxic and mutagenic, new forms of the supplement have been proposed. These include the trinuclear chromium(III) propionate complex $\left[\mathrm{Cr}_{3} \mathrm{O}\left(\mathrm{EtCO}_{2}\right)_{6}\left(\mathrm{H}_{2} \mathrm{O}\right)_{3}\right]^{+}$, which reduces blood levels of cholesterol and triglyceride in healthy and type II diabetic mices, and thus has been proposed as a structural and functional mimetic compound of chromodulin, a peptide containing Cr(III) [6].

In order to investigate how the coordination of a representative flavonoid with trinuclear chromium(III) complexes affects their antiradical properties, in this work we have synthesized and characterized a new complex with primuletin (5-hydroxyflavone) as the ligand (Figure 1). The product, which has a formulation $\left[\mathrm{Cr}_{3} \mathrm{O}\left(\mathrm{CH}_{3} \mathrm{CO}_{2}\right)_{6}(\mathrm{Pri})\left(\mathrm{H}_{2} \mathrm{O}\right)_{2}\right]$ with primuletin (HPri) in its deprotonated monoanionic state $\left(\mathrm{Pri}^{-}\right)$, was prepared from $\left[\mathrm{Cr}_{3} \mathrm{O}\left(\mathrm{CH}_{3} \mathrm{CO}_{2}\right)_{6}\left(\mathrm{H}_{2} \mathrm{O}\right)_{3}\right] \mathrm{Cl}$ [7] and structurally analyzed by the methods detailed in the Experimental Section.

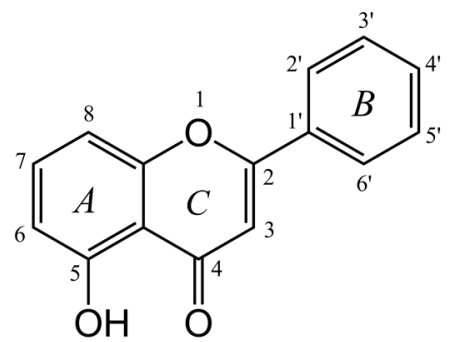

HPri

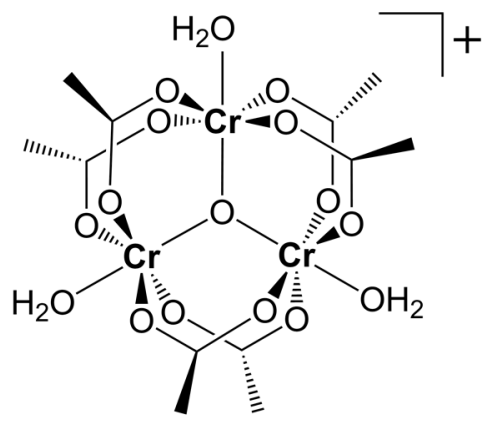

$\mathrm{Cr}_{3} \mathrm{O}$

Figure 1. The flavonoid primuletin (HPri) and starting complex $\left[\mathrm{Cr}_{3} \mathrm{O}\left(\mathrm{CH}_{3} \mathrm{CO}_{2}\right)_{6}\left(\mathrm{H}_{2} \mathrm{O}\right)_{3}\right]^{+}$ $\left(\mathrm{Cr}_{3} \mathrm{O}\right)$. Upon metal coordination, primuletin as ligand is deprotonated $\left(\mathrm{Pri}^{-}\right)$. 


\section{Results and Discussion}

The complex was found to be almost insoluble in most common solvents, with best solubility in dimethylsulfoxide (DMSO). Thus, its molar conductivity was obtained by comparison with a $10^{-5} \mathrm{M}$ solution of $\mathrm{KCl}$, and not with a $10^{-3} \mathrm{M}$ solution as described in the literature [8]. Consistent with the molecular formulation of the neutral complex $\left[\mathrm{Cr}_{3} \mathrm{O}\left(\mathrm{CH}_{3} \mathrm{CO}_{2}\right)_{6}(\mathrm{Pri})\left(\mathrm{H}_{2} \mathrm{O}\right)_{2}\right]$, the obtained low conductivity value $\left(65 \mathrm{~S} \mathrm{~cm}^{2} \cdot \mathrm{mol}^{-1}\right)$ indicates that this species behaves as a non-electrolyte.

The ESI mass spectrum of $\left[\mathrm{Cr}_{3} \mathrm{O}\left(\mathrm{CH}_{3} \mathrm{CO}_{2}\right)_{6}(\mathrm{Pri})\left(\mathrm{H}_{2} \mathrm{O}\right)_{2}\right]$ (Figure S1) displays a base peak with $\mathrm{m} / \mathrm{z}$ of 739.5 for $\left[\mathrm{Cr}_{3} \mathrm{O}\left(\mathrm{CH}_{3} \mathrm{CO}_{2}\right)_{5}(\mathrm{Pri})\left(\mathrm{H}_{2} \mathrm{O}\right)_{2}\right]^{+}$and several other peaks assigned to fragmented species, such as $\left[\mathrm{Cr}_{3} \mathrm{O}\left(\mathrm{CH}_{3} \mathrm{CO}_{2}\right)_{6}\right]^{+}$with $\mathrm{m} / z$ of 526.0. The data thus confirm that the trigonal oxo-cluster core $\left(\mathrm{Cr}_{3} \mathrm{O}\right)$ is maintained in the complex.

The thermogravimetric (TG) curve of primuletin showed that this compound is stable up to $190{ }^{\circ} \mathrm{C}$, while the starting complex $\left[\mathrm{Cr}_{3} \mathrm{O}\left(\mathrm{CH}_{3} \mathrm{CO}_{2}\right)_{6}\left(\mathrm{H}_{2} \mathrm{O}\right)_{3}\right] \mathrm{Cl}$ presented mass loss from the beginning of heating. In the region of $25-158^{\circ} \mathrm{C}$, this precursor showed a mass loss of $14.5 \%$, which corresponds to the release of water molecules and $\mathrm{Cl}^{-}$as chlorine. The loss of acetates begins at $158{ }^{\circ} \mathrm{C}$, with the release of four groups below $600{ }^{\circ} \mathrm{C}$ and the remaining ones at higher temperatures (Table 1 and Figure S2). The decomposition process of the product $\left[\mathrm{Cr}_{3} \mathrm{O}\left(\mathrm{CH}_{3} \mathrm{CO}_{2}\right)_{6}(\mathrm{Pri})\left(\mathrm{H}_{2} \mathrm{O}\right)_{2}\right]$ occurs in four stages, starting with the loss of water molecules $(4.5 \%)$ up to approximately $97{ }^{\circ} \mathrm{C}$. The loss of the more weakly bound, non-bridging acetate (see below) occurs in the region of $97-272{ }^{\circ} \mathrm{C}$ with an observed and calculated mass loss of $7.4 \%$. The release of the flavonoid is observed in the region of $272-585{ }^{\circ} \mathrm{C}$ (with observed and calculated loss of $28.9 \%$ and $29.7 \%$ ), followed by removal of acetate groups extending to and beyond $900{ }^{\circ} \mathrm{C}$ (Table 1 and Figure S2).

Table 1. Thermogravimetric data for the starting compounds $\left[\mathrm{Cr}_{3} \mathrm{O}\left(\mathrm{CH}_{3} \mathrm{CO}_{2}\right)_{6}\left(\mathrm{H}_{2} \mathrm{O}\right)_{3}\right] \mathrm{Cl}$ $\left(\mathrm{Cr}_{3} \mathrm{O}\right)$ and primuletin (HPri), and the product complex $\left[\mathrm{Cr}_{3} \mathrm{O}\left(\mathrm{CH}_{3} \mathrm{CO}_{2}\right)_{6}(\mathrm{Pri})\left(\mathrm{H}_{2} \mathrm{O}\right)_{2}\right]$ $\left(\mathrm{Cr}_{3} \mathrm{O}-\mathrm{Pri}\right)$.

\begin{tabular}{|c|c|c|c|c|c|c|}
\hline \multirow{2}{*}{ Compound } & \multicolumn{3}{|c|}{ Dehydration Process } & \multicolumn{3}{|c|}{ Decomposition Process } \\
\hline & $\Delta T\left({ }^{\circ} \mathrm{C}\right)$ & $\Delta m_{\exp }(\%)$ & $\Delta m_{\text {calc }}(\%)$ & $\Delta T\left({ }^{\circ} \mathrm{C}\right)$ & $\Delta m_{\exp }(\%)$ & $\Delta m_{\text {calc }}(\%)$ \\
\hline $\mathrm{Cr}_{3} \mathrm{O}$ & $25-158$ & 14.5 & 14.4 & $158-600$ & 39.5 & $38.3\left(4 \mathrm{Ac}^{-}\right)$ \\
\hline HPri & - & - & - & $190-232$ & 100 & 100 \\
\hline \multirow{3}{*}{$\mathrm{Cr}_{3} \mathrm{O}-\mathrm{Pri}$} & & & & $97-272$ & 7.4 & $7.4\left(1 \mathrm{Ac}^{-}\right)$ \\
\hline & $25-97$ & 4.5 & 4.6 & $272-585$ & 28.9 & 29.7 (Pri) \\
\hline & & & & $585-860$ & 22.2 & $22.1\left(3 \mathrm{Ac}^{-}\right)$ \\
\hline
\end{tabular}

$\Delta T=$ temperature range; $\Delta m_{\exp }=$ experimental mass loss; $\Delta m_{\text {calc }}=$ calculated mass loss; $\mathrm{Ac}^{-}=\mathrm{CH}_{3} \mathrm{CO}_{2}^{-}$.

The ${ }^{1} \mathrm{H}-\mathrm{NMR}$ spectrum of primuletin was obtained in DMSO- $d_{6}$ (Figure S3a). The four signals with $\delta 6.74(1 \mathrm{H}, \mathrm{dd}, J=8.3 \mathrm{~Hz} ; 1.0 \mathrm{~Hz}), \delta 7.13(1 \mathrm{H}, \mathrm{dd}, J=8.4 \mathrm{~Hz} ; 1.0 \mathrm{~Hz}), \delta 7.60(1 \mathrm{H}, \mathrm{dd}, J=8.4 \mathrm{~Hz}$ and $8.3 \mathrm{~Hz})$, and $\delta 8.03(2 \mathrm{H}, \mathrm{dd}, J=8.1 \mathrm{~Hz} ; 1.8 \mathrm{~Hz})$ were assigned to $\mathrm{H} 6, \mathrm{H} 8, \mathrm{H} 7$ and $\mathrm{H} 2^{\prime} / \mathrm{H} 6{ }^{\prime}$, respectively. Additionally, two multiplets at $\delta 7.50(2 \mathrm{H})$ and $\delta 7.53(1 \mathrm{H})$ were assigned to $\mathrm{H} 3^{\prime} / \mathrm{H} 5^{\prime}$ and $\mathrm{H} 4$ ', respectively. The presence of two singlets at $\delta 7.01(1 \mathrm{H})$ and $\delta 12.6(1 \mathrm{H})$ were assigned to $\mathrm{H} 3$ and the hydrogen of the hydroxyl at $\mathrm{C} 5$. These assignments are in agreement with the literature $[9,10]$. The spectrum of the complex $\left[\mathrm{Cr}_{3} \mathrm{O}\left(\mathrm{CH}_{3} \mathrm{CO}_{2}\right)_{6}(\mathrm{Pri})\left(\mathrm{H}_{2} \mathrm{O}\right)_{2}\right]$ in DMSO- $d_{6}$ (Figure S3b) showed only a broad signal at $\delta 8.5$ due to the high paramagnetism of the three $\operatorname{Cr}(\mathrm{III})$ ions, which promotes spin 
relaxation and absence of most signals. This typical paramagnetic behavior has been observed in other chromium complexes.

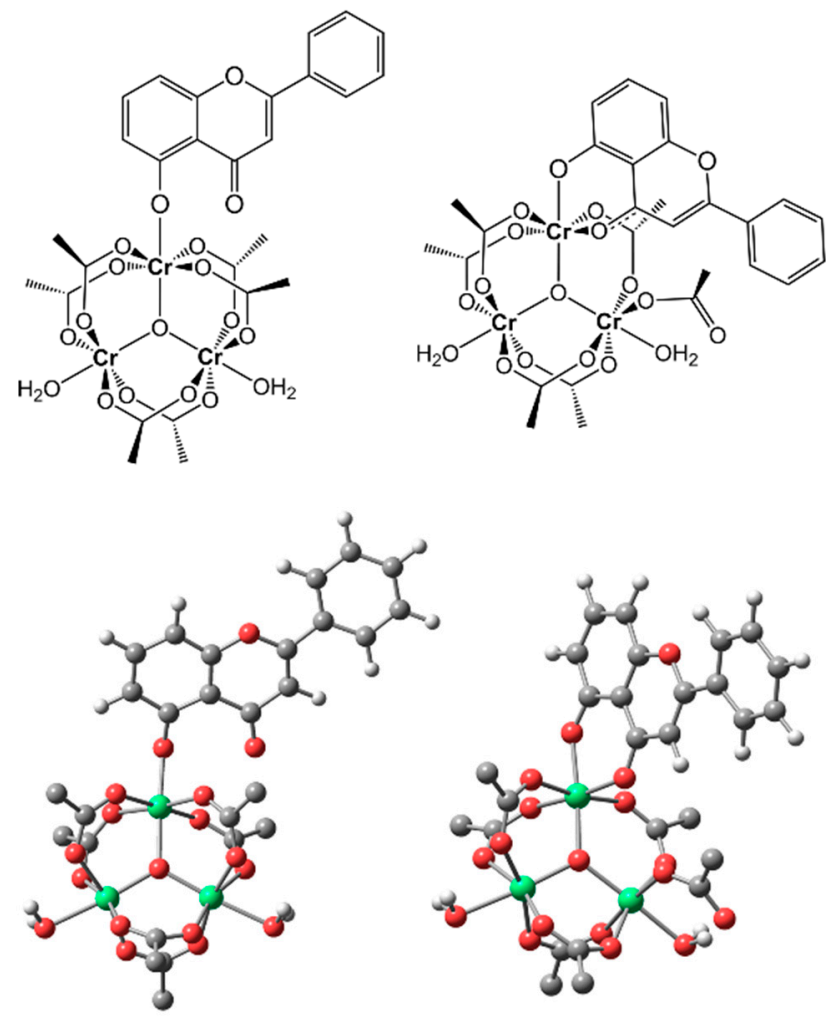

Figure 2. Drawing (top) and fully optimized density functional theory (DFT) structures (bottom) of the monodentate (left) and bidentate (right) isomers of the trinuclear $\mathrm{Cr}$ (III) complex with primuletin, formally $\left[\mathrm{Cr}_{3} \mathrm{O}\left(\mu-\mathrm{CH}_{3} \mathrm{CO}_{2}\right)_{6}\left(O^{5}-\mathrm{Pri}\right)\left(\mathrm{H}_{2} \mathrm{O}\right)_{2}\right]$ and $\left[\mathrm{Cr}_{3} \mathrm{O}\left(\mu-\mathrm{CH}_{3} \mathrm{CO}_{2}\right)_{5}\left(\mathrm{CH}_{3} \mathrm{CO}_{2}\right)\left(O^{5}, O^{4}-\mathrm{Pri}\right)\left(\mathrm{H}_{2} \mathrm{O}\right)_{2}\right]$, respectively (the hydrogen atoms of acetate groups are omitted for clarity; color legend: $\mathrm{Cr}=$ green, $\mathrm{O}=$ red, and $\mathrm{C}=$ dark gray). Selected structural parameters are provided as Supplementary Material (Table S2).

Although primuletin is known to coordinate with metal ions as a bidentate ligand, trinuclear oxo-centered clusters of the type $\left[\mathrm{M}_{3} \mathrm{O}\left(\mathrm{CH}_{3} \mathrm{CO}_{2}\right)_{6}\left(\mathrm{H}_{2} \mathrm{O}\right)_{3}\right]^{+}$generally form complexes via substitution of the peripheral water ligands by monodentate species [11]. In order to elucidate which of these forms (i.e., monodentate or bidentate) is favored in this specific flavonoid complex, the molecular structure of $\left[\mathrm{Cr}_{3} \mathrm{O}\left(\mathrm{CH}_{3} \mathrm{CO}_{2}\right)_{6}(\mathrm{Pri})\left(\mathrm{H}_{2} \mathrm{O}\right)_{2}\right]$ was computationally studied by DFT calculations (see Computational Details). Full geometry optimizations at the B3LYP//6-31G*(C,H,O)/LANL2TZ(Cr) level were performed for both isomers shown in Figure 2: monodentate binding via the deprotonated hydroxyl $(\mathrm{O} 5$, ring $A)$, and bidentate binding via hydroxyl $(\mathrm{O} 5$, ring $A)$ and carbonyl $(\mathrm{O} 4$, ring $C)$ groups. The geometry of the precursor $\left[\mathrm{Cr}_{3} \mathrm{O}\left(\mathrm{CH}_{3} \mathrm{CO}_{2}\right)_{6}\left(\mathrm{H}_{2} \mathrm{O}\right)_{3}\right]^{+}$was also optimized at the same level of theory for comparison with its reported crystal structure [12]; the calculated bond distances/angles are in excellent agreement with the experimental data (Table S1). Starting from this tris-aqua complex to form $\left[\mathrm{Cr}_{3} \mathrm{O}\left(\mathrm{CH}_{3} \mathrm{CO}_{2}\right)_{6}(\mathrm{Pri})\left(\mathrm{H}_{2} \mathrm{O}\right)_{2}\right]$, the monodentate coordination of the flavonoid involves only the peripheral substitution of a water ligand, while the bidentate product involves additional displacement of an $\mathrm{O}$ atom of one of the six equatorially bridging acetates; that is, an acetate adjacent to the bidentate flavonoid loses its role as a 
bridge and becomes bound to a Cr(III) as a monodentate ligand (Figure 2). The DFT data clearly indicated that the isomer coordinated in a bidentate mode makes for the most stable structure. The energy difference favoring the bidentate isomer relative to the monodentate isomer is substantial: $15.68 \mathrm{kcal} \mathrm{mol}^{-1}$ (obtained at the B3LYP/6-311+G(2d,2p) level). This result is consistent with the mass spectra, which showed that the base peak has only five acetates. Moreover, the thermogravimetric analysis indicated the loss of one weakly bound acetate much before the other bridging acetate groups. A similar behavior was observed by Chaudhary and Van Horn [13].

The UV-Vis absorption spectrum of free primuletin in DMSO (Figure 3 and Table 2) displays two defined bands at $273 \mathrm{~nm}$ and $337 \mathrm{~nm}$ and a shoulder around $300 \mathrm{~nm}$. By comparison with the literature of flavonoids [10,14], the bands at $337 \mathrm{~nm}$ (band I) and $273 \mathrm{~nm}$ (band II) were assigned to $\pi \rightarrow \pi^{*}$ electronic transitions originating at the flavonoid $\operatorname{ring} B$ (cinnamoyl system) and $\operatorname{ring} A$ (benzoyl system), respectively. For the complex $\left[\mathrm{Cr}_{3} \mathrm{O}\left(\mathrm{CH}_{3} \mathrm{CO}_{2}\right)_{6}(\mathrm{Pri})\left(\mathrm{H}_{2} \mathrm{O}\right)_{2}\right]$, these bands are shifted to $426 \mathrm{~nm}$ and $301 \mathrm{~nm}$, confirming the metal-flavonoid coordination. The spectra were obtained at different concentrations due the poor solubility of the complex.

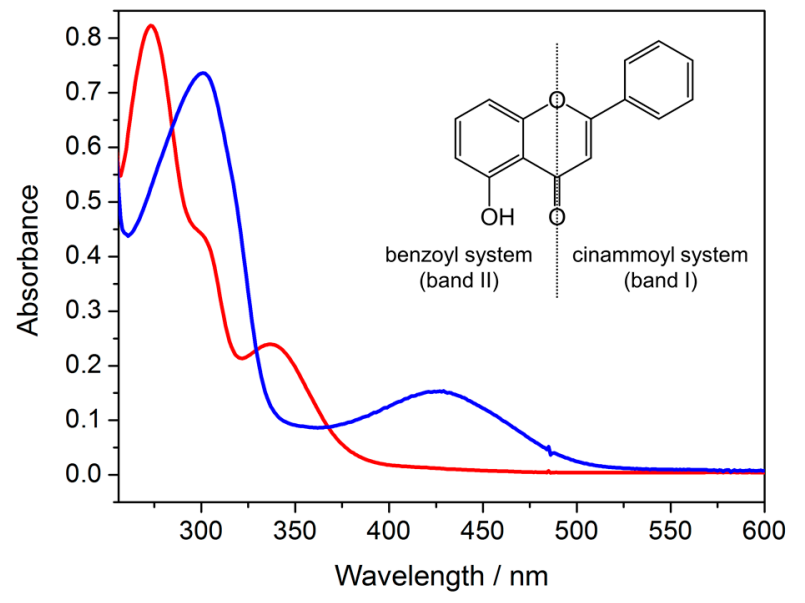

Figure 3. UV-Vis spectra of dimethylsulfoxide (DMSO) solutions of $43.1 \mu \mathrm{M}$ primuletin (red line) and $18.8 \mu \mathrm{M}\left[\mathrm{Cr}_{3} \mathrm{O}\left(\mathrm{CH}_{3} \mathrm{CO}_{2}\right)_{6}(\mathrm{Pri})\left(\mathrm{H}_{2} \mathrm{O}\right)_{2}\right]$ (blue line).

Table 2. Absorption maxima $(\lambda, \mathrm{nm})$ and molar absorptivities $\left(\varepsilon, \mathrm{M}^{-1} \cdot \mathrm{cm}^{-1}\right)$ of the main bands observed in the UV-Vis spectra of primuletin (HPri) and complex $\left[\mathrm{Cr}_{3} \mathrm{O}\left(\mathrm{CH}_{3} \mathrm{CO}_{2}\right)_{6}(\mathrm{Pri})\left(\mathrm{H}_{2} \mathrm{O}\right)_{2}\right] \quad\left(\mathrm{Cr}_{3} \mathrm{O}-\mathrm{Pri}\right)$ in DMSO, and starting complex $\left[\mathrm{Cr}_{3} \mathrm{O}\left(\mathrm{CH}_{3} \mathrm{CO}_{2}\right)_{6}\left(\mathrm{H}_{2} \mathrm{O}\right)_{3}\right]^{+}\left(\mathrm{Cr}_{3} \mathrm{O}\right)$ in ethanol.

\begin{tabular}{cccc}
\hline Compound & Band II $(\boldsymbol{\pi} \rightarrow \boldsymbol{\pi} *)$ & Band I $\left(\boldsymbol{\pi} \rightarrow \boldsymbol{\pi}^{*}\right)$ & Ligand Field $(\mathbf{d} \rightarrow \mathbf{d})$ \\
\hline $\mathrm{HPri}$ & $273\left(2.8 \times 10^{4}\right)$ & $337\left(8.0 \times 10^{3}\right)$ & - \\
$\mathrm{Cr}_{3} \mathrm{O}-\mathrm{Pri}$ & $301\left(2.9 \times 10^{4}\right)$ & $426\left(8.1 \times 10^{3}\right)$ & $-^{\text {(a) }}$ \\
$\mathrm{Cr}_{3} \mathrm{O}$ & - & - & $442,588(<100)$ \\
\hline
\end{tabular}

(a) Too weak; masked by the intense band I.

The IR spectra of primuletin and its complex are shown in Figure S4, and tentative assignments of the main peaks are collected in Table 3. The peak for the carbonyl stretching mode of primuletin appears at $1655 \mathrm{~cm}^{-1}$ [15]; following coordination to $\mathrm{Cr}$ (III), it is downshifted to $1626 \mathrm{~cm}^{-1}\left(\Delta v=29 \mathrm{~cm}^{-1}\right)$. This trend has been observed in the vibrational spectra of primuletin with other metals [16,17] and 
confirms the involvement of the carbonyl oxygen (O4) in the metal binding. The low-frequency vibrations in the region of $600-400 \mathrm{~cm}^{-1}$ are characteristic of the trinuclear cluster core, $v\left(\mathrm{Cr}_{3} \mathrm{O}\right)$ and $v\left(\mathrm{CrO}_{4}\right)$ [11]. The two peaks at 627 and $525 \mathrm{~cm}^{-1}$ clearly indicate that the central $\mathrm{Cr}_{3} \mathrm{O}$ unit is preserved upon coordination to the flavonoid.

Table 3. FTIR data for free primuletin (HPri), precursor $\left[\mathrm{Cr}_{3} \mathrm{O}\left(\mathrm{CH}_{3} \mathrm{CO}_{2}\right)_{6}\left(\mathrm{H}_{2} \mathrm{O}\right)_{3}\right]\left(\mathrm{Cr}_{3} \mathrm{O}\right)$, and complex $\left[\mathrm{Cr}_{3} \mathrm{O}\left(\mathrm{CH}_{3} \mathrm{CO}_{2}\right)_{6}(\mathrm{Pri})\left(\mathrm{H}_{2} \mathrm{O}\right)_{2}\right]\left(\mathrm{Cr}_{3} \mathrm{O}-\mathrm{Pri}\right)$.

\begin{tabular}{|c|c|c|c|c|c|c|}
\hline \multirow[t]{2}{*}{ Compound } & \multicolumn{3}{|c|}{ Flavonoid } & \multicolumn{2}{|c|}{ Acetate } & \multirow[t]{2}{*}{$\mathrm{Cr}-\mathrm{O}$} \\
\hline & $v(\mathrm{C}=\mathrm{O})$ & $v\left(C_{2}=C_{3}\right)$ & $\delta(\mathrm{C}-\mathrm{OH})$ & $v_{\mathrm{s}}(\mathrm{COO})$ & $v_{\mathrm{as}}(\mathrm{COO})$ & \\
\hline $\mathrm{Cr}_{3} \mathrm{O}$ & - & - & - & 1450 vs & 1611 vs & $\begin{array}{c}665 \mathrm{~s} \\
442 \mathrm{~m}\end{array}$ \\
\hline primuletin & 1655 vs & $1587 \mathrm{w}$ & $1319 \mathrm{vw}$ & - & - & - \\
\hline $\mathrm{Cr}_{3} \mathrm{O}-\mathrm{Pri}$ & 1626 vs & $1576 \mathrm{w}$ & - & 1445 vs & $1593 \mathrm{~m}$ & $\begin{array}{l}627 \mathrm{w} \\
525 \mathrm{w}\end{array}$ \\
\hline
\end{tabular}

Abbreviations: $\mathrm{vs}=$ very strong; $\mathrm{s}=$ strong; $\mathrm{m}=$ medium; $\mathrm{w}=$ weak; $\mathrm{vw}=$ very weak; $\mathrm{v}=$ stretching; as = asymmetric; $\mathrm{s}=$ symmetric.

In the studies of antiradical properties, stock solutions of free and coordinated primuletin $(0.1 \mathrm{~mL}$, DMSO) were added to a $60 \mu \mathrm{M}$ solution of DPPH (2,2-diphenyl-1-picrylhydrazyl) in methanol (3.9 mL). The reaction kinetics was followed by the change in absorbance at $515 \mathrm{~nm}$ during $45 \mathrm{~min}$. To quantify the antiradical activity of the tested samples, the absorbance gradient ( $\Delta \mathrm{Abs})$ was calculated by considering the absorbance of DPPH at time zero (i.e., before addition of the samples) and then $45 \mathrm{~min}$ after mixing with the flavonoid samples [18]. From this procedure, the concentration of scavenged $\mathrm{DPPH}\left(\mathrm{DPPH}_{\mathrm{seq}}\right)$ was calculated as $\left[\mathrm{DPPH}_{\text {seq }}\right]=\Delta \mathrm{Abs} /(b \times \varepsilon 515)$, where $\varepsilon 515$ is the molar absorptivity of DPPH at $515 \mathrm{~nm}\left(1.13 \times 10^{4} \mathrm{M}^{-1} \cdot \mathrm{cm}^{-1}\right)$ and $b$ is the optical path length of the cuvette $(1.0 \mathrm{~cm})$. Thus, the number $(n)$ of DPPH radicals sequestrated per molecule of the flavonoid sample (flav) was estimated as $n=\left[\mathrm{DPPH}_{\text {seq }}\right] /[\mathrm{flav}]$. The flavonoid quercetin was used as standard antiradical in this work.

The obtained $n$ values (Table 4) indicate that complexation led to an increase in the antiradical activity of the flavonoid, as $n$ is higher for the complex compared to free primuletin. Further studies will be aimed at mechanistic details, although it is known that the antiradical activity of the flavonoid may occur via hydrogen atom transfer (HAT) and sequential proton loss electron transfer (SPLET) [19]. However, since primuletin becomes deprotonated upon coordination, SPLET is the only plausible mechanism in the complex $\left[\mathrm{Cr}_{3} \mathrm{O}\left(\mathrm{CH}_{3} \mathrm{CO}_{2}\right)_{6}(\mathrm{Pri})\left(\mathrm{H}_{2} \mathrm{O}\right)_{2}\right]$. This interpretation agrees with the observation that the complex $\left[\mathrm{CrCl}(\mathrm{Q})_{2}\left(\mathrm{H}_{2} \mathrm{O}\right)\right](\mathrm{Q}=$ quercetin $)$ has a higher antiradical activity than that of free quercetin, from which it was concluded that $\mathrm{Cr}(\mathrm{III})$ is a better electron donor than the $\mathrm{H}$ atom [20].

Table 4. Antiradical activities of free and coordinated primuletin based on DPPH assays.

\begin{tabular}{ccccc}
\hline Compound & $\boldsymbol{\Delta A b s}$ & {$\left[\mathbf{D P P H}_{\text {seq }}\right]$} & [flav] & $\boldsymbol{n}$ \\
\hline HPri & 0.017 & $1.50 \times 10^{-6}$ & $1.01 \times 10^{-5}$ & 0.155 \\
$\mathrm{Cr}_{3} \mathrm{O}-$ Pri & 0.020 & $1.77 \times 10^{-6}$ & $2.50 \times 10^{-6}$ & 0.734 \\
\hline
\end{tabular}

$\Delta \mathrm{Abs}=$ total change in absorbance for DPPH; $\left[\mathrm{DPPH}_{\mathrm{seq}}\right]=$ concentration of DPPH scavenged by the flavonoid sample; [flav] = flavonoid concentration; $n=$ number of DPPH radicals scavenged per molecule of the flavonoid (free or coordinated). 


\section{Experimental Section}

The starting compound $\left[\mathrm{Cr}_{3} \mathrm{O}\left(\mathrm{CH}_{3} \mathrm{CO}_{2}\right)_{6}\left(\mathrm{H}_{2} \mathrm{O}\right)_{3}\right] \mathrm{Cl}$ was synthesized as described in the literature [7]. All reagents and solvents were analytical grade. Elemental analyses $(\mathrm{C}, \mathrm{H})$ were performed using a Perkin Elmer CHN 2400. Molar conductance was measured for DMSO solutions (0.01-1.0 mM range) using a Digimed DM-32 conductivity meter. ESI mass spectra in positive mode were carried out with a Bruker Daltonics Esquire 3000 plus ESI-MS with dry temperature of $280{ }^{\circ} \mathrm{C}$ and capillary voltage of $4 \mathrm{kV}$; the sample was dispersed in acetonitrile and $\mathrm{N}_{2}$ was used as auxiliary gas. Thermogravimetric analyses were performed with a TA Instruments TGA $2950 \mathrm{Hi}$-Res thermogravimetric analyzer using 1-3 $\mathrm{mg}$ samples in a ceramic crucible, nitrogen flow at $50 \mathrm{~mL} \cdot \mathrm{min}^{-1}$, and heating rate of $10^{\circ} \mathrm{C} \cdot \mathrm{min}^{-1}$. Infrared spectra from 4000 to $400 \mathrm{~cm}^{-1}$ were obtained with a Shimadzu FTIR 8400 instrument, using $\mathrm{KBr}$ pellets. Electronic absorption spectra in the region of 190-1100 nm were recorded on an Agilent $8453 \mathrm{UV}$-visible spectrophotometer. ${ }^{1} \mathrm{H}-\mathrm{NMR}$ spectra of complexes and free flavonoids in DMSO-d6 or $\mathrm{CD}_{3} \mathrm{OD}$ were collected on a Bruker DPX 300 spectrometer $\left({ }^{1} \mathrm{H} / 300 \mathrm{MHz}\right)$.

\subsection{Synthesis of $\left[\mathrm{Cr}_{3} \mathrm{O}\left(\mathrm{CH}_{3} \mathrm{CO}_{2}\right)_{6}(\mathrm{Pri})\left(\mathrm{H}_{2} \mathrm{O}\right)_{2}\right]$}

The complex with primuletin (Pri) was prepared as reported in the literature [16]. A mixture containing $0.252 \mathrm{~g}(1.06 \mathrm{mmol})$ of primuletin, $0.040 \mathrm{~g}(1.01 \mathrm{mmol})$ of $\mathrm{NaOH}, 165 \mathrm{~mL}$ of ethanol, and $10 \mathrm{~mL}$ of water was heated under reflux for $15 \mathrm{~h}$. Then, $0.221 \mathrm{~g}(0.33 \mathrm{mmol})$ of $\left[\mathrm{Cr}_{3} \mathrm{O}\left(\mathrm{CH}_{3} \mathrm{CO}_{2}\right)\left(\mathrm{H}_{2} \mathrm{O}\right)_{3}\right] \mathrm{Cl} \cdot 3 \mathrm{H}_{2} \mathrm{O}$ in ethanol $(5 \mathrm{~mL})$ was added to the mixture under reflux. After $10 \mathrm{~h}$ of reaction, the solution was cooled to $5{ }^{\circ} \mathrm{C}$ and the obtained brown precipitate was filtered, washed with cold water and dried under vacuum. Yield: $26 \%$. Anal. Calcd for $\mathrm{C}_{27} \mathrm{H}_{31} \mathrm{O}_{18} \mathrm{Cr}_{3}$ (MW = 799.5): C, 40.5; H, 3.91. Found: $\mathrm{C}, 40.2$; H, 4.08 .

\subsection{Computational Details}

Density functional theory (DFT) calculations were carried out using the Gaussian 09 program (revision D.01) [21]. Geometry optmizations without any constraints employed the hybrid B3LYP functional with the LANL2TZ relativistic effective core potentials and associated triple-zeta basis set for chromium and the 6-31G(d) basis set for all the other elements. In order to evaluate the quality of the results produced by this methodology, the structure of a reference system (the tris-aquo precursor $\left.\left[\mathrm{Cr}_{3} \mathrm{O}\left(\mathrm{CH}_{3} \mathrm{CO}_{2}\right)_{6}\left(\mathrm{H}_{2} \mathrm{O}\right)_{3}\right]^{+}\right)$was also computed and shown to be in excellent agreement with crystallographic data [12] (Table S1). Single-point energy calculations following geometry optimization were carried out using the triple-zeta $6-311+\mathrm{G}(2 \mathrm{~d}, 2 \mathrm{p})$ basis set; total energies for monodentate and bidentate isomers were -5536.514421 a.u. and -5536.539404 a.u., respectively. Since the complexes in this study have three $\mathrm{Cr}(\mathrm{III})$ centers with three unpaired electrons each $\left(3 d^{3}\right)$, all calculations involved open-shell systems with spin multiplicity $M_{\mathrm{s}}=10$ (dectet).

\section{Conclusions}

In conclusion, the metal-ligand association between a trinuclear oxo-Cr(III) cluster and the flavonoid primuletin as ligand produced the complex $\left[\mathrm{Cr}_{3} \mathrm{O}\left(\mathrm{CH}_{3} \mathrm{CO}_{2}\right)_{6}(\mathrm{Pri})\left(\mathrm{H}_{2} \mathrm{O}\right)_{2}\right]$. The molecular structure of this product was elucidated through a combination of experimental and theoretical 
methods. The results showed that the $\mathrm{Cr}_{3} \mathrm{O}$ cluster core is retained upon complexation, and that the flavonoid binds to one of the metal centers in a bidentate mode via the 5-hydroxy/4-oxo groups. The studies involving the reaction between the free radical DPPH and the flavonoid (free and coordinated) indicated that complexation with the trinuclear cluster enhanced the antiradical activity of the flavonoid.

\section{Supplementary Materials}

Supplementary materials can be accessed at: http://www.mdpi.com/1420-3049/20/04/6310/s1.

\section{Acknowledgments}

Fundo Mackenzie de Pesquisa.

\section{Author Contributions}

A.D.P.A. designed the research. A.D.P.A., C.C.D., S.N.A, M.J.P.F., and P.R. performed the experimental work. A.D.P.A. and R.C.R. performed the theoretical work. A.D.P.A., M.J.P.F., P.R., and R.C.R. analyzed the data and wrote the paper.

\section{Conflicts of Interest}

The authors declare no conflict of interest.

\section{References}

1. Andersen, Ø.M.; Markham, K.R. Flavonoids: Chemistry, Biochemistry, and Applications; CRC Press, Taylor \& Francis Group: Boca Raton, FL, USA, 2006.

2. Perron, N.R.; Hodges, J.N.; Jenkins, M.; Brumaghim, J.L. Predicting How Polyphenol Antioxidants Prevent DNA Damage by Binding to Iron. Inorg. Chem. 2008, 47, 6153-6161.

3. Afanas'eva, I.B.; Ostrakhovitch, E.A.; Mikhal'chik, E.V.; Ibragimova, G.A.; Korkina, L.G. Enhancement of Antioxidant and Anti-inflammatory Activities of Bioflavonoid Rutin by Complexation with Transition Metals. Biochem. Pharmacol. 2001, 61, 677-684.

4. Souza, R.F.V.; Giovani, W.F. Antioxidant Properties of Complexes of Flavonoids with Metal Ions. Redox Rep. 2004, 9, 97-104.

5. Li, Y.; Yang, Z.; Li, T. Synthesis, Characterization, Antioxidative Activity and DNA Binding Properties of the Copper(II), Zinc(II), Nickel(II) Complexes with 1,2-Di(4'-iminonaringenin)ethane. Chem. Pharm. Bull. 2004, 56, 1528-1534.

6. Nguyen, A.; Mulyani, I.; Levina, A.; Lay, P.A. Reactivity of Chromium(III) Nutritional Supplements in Biological Media: An X-Ray Absorption Spectroscopic Study. Inorg. Chem. 2008, 47, 4299-4309.

7. Uemura, S.; Spencer, A.; Wilkinson, G. $\mu_{3}$-Oxotrimetal Acetato-Complexes of Chromium, Manganese, Iron, Cobalt, Rhodium, and Iridium. J. Chem. Soc. Dalton Trans. 1973, 2565-2571, doi:10.1039/DT9730002565.

8. Geary, W.J. The Use of Conductivity Measurements in Organic Solvents for the Characterization of Coordination Compounds. Coord. Chem. Rev. 1971, 7, 81-122. 
9. Park, Y.; Moon, B.-H.; Lee, E.; Lee, Y.; Yoon, Y.; Ahn, J.-H.; Lim, Y. ${ }^{1} \mathrm{H}$ and ${ }^{13} \mathrm{C}-\mathrm{NMR}$ Data of Hydroxyflavone Derivatives. Magn. Reson. Chem. 2007, 45, 674-679.

10. Mabry, T.; Markham, K.R.; Thomas, M.B. The Systematic Investigation of Flavonoids; Springer: New York, NY, USA, 1970.

11. Cannon, R.D.; White, R.P. Chemical and Physical Properties of Triangular Bridged Metal Complexes. Prog. Inorg. Chem. 1988, 36, 195-298.

12. Anson, C.E.; Bourke, J.P.; Cannon, R.D.; Jayasooriya, U.A.; Molinier, M.; Powell, A.K. Crystal Structures of the Isomorphous Prototypic Oxo-Centered Trinuclear Complexes $\left[\mathrm{Cr}_{3} \mathrm{O}\left(\mathrm{OOCCH}_{3}\right)_{6}\left(\mathrm{H}_{2} \mathrm{O}\right)_{3}\right] \mathrm{Cl} \cdot 6 \mathrm{H}_{2} \mathrm{O}$ and $\left[\mathrm{Fe}_{3} \mathrm{O}\left(\mathrm{OOCCH}_{3}\right)_{6}\left(\mathrm{H}_{2} \mathrm{O}\right)_{3}\right] \mathrm{Cl} \cdot 6 \mathrm{H}_{2} \mathrm{O}$. Inorg. Chem. 1997, $36,1265-1267$.

13. Chaudhary, S.; van Horn, J.D. Breakdown Kinetics of the Tri-chromium(III) Oxo Acetate Cluster $\left(\left[\mathrm{Cr}_{3} \mathrm{O}(\mathrm{OAc})_{6}\right]^{+}\right)$with Some Ligands of Biological Interest J. Inorg. Biochem. 2007, 101, 329-335.

14. Markham, K.R. Techniques of Flavonoid Identification; Academic Press: London, UK, 1982.

15. Teslova, T.; Corredor, C.; Livingstone, R.; Spataru, T.; Birke, R.L.; Lombardi, J.R.; Canãmares, M.V.; Leona, M. Raman and Surface-enhanced Raman Spectra of Flavone and Several Hydroxy Derivatives. J. Raman Spectrosc. 2007, 38, 802-818.

16. Hiraki, K.; Onishi, M.; Ikeda, T.; Tomioka, K.; Obayashi, Y. Syntheses of 5-Hydroxyflavone-Transition Metal Complexes. Bull. Chem. Soc. Jpn. 1978, 51, 2425-2426.

17. Uivarosi, V.; Badea, M.; Olar, R.; Draghici, C.; Barbuceanu, S.F. Synthesis and Characterization of Some New Complexes of Magnesium (II) and Zinc (II) with the Natural Flavonoid Primuletin. Molecules 2013, 18, 7631-7645.

18. Eckert, C.R. Determination of the Antiradical Activity of Flavonoids and Extracts of the Species Baccharis by the Chemiluminescent Luminol Reaction. Master of Science Dissertation, University of São Paulo, São Paulo, SP, Brazil, 2006.

19. Liu, Z.-Q. Chemical Methods to Evaluate Antioxidant Ability. Chem. Rev. 2010, 110, 5675-5691.

20. Chen, W.; Sun, S.; Cao, W.; Liang, Y.; Song, J. Antioxidant Property of Quercetin-Cr(III) Complex: The Role of Cr(III) Ion. J. Mol. Struct. 2009, 918, 194-197.

21. Frisch, M.J.; Trucks, G.W.; Schlegel, H.B.; Scuseria, G.E.; Robb, M.A.; Cheeseman, J.R.; Scalmani, G.; Barone, V.; Mennucci, B.; Petersson, G.A.; et al. Gaussian 09, Revision D.01, Gaussian, Inc.: Wallingford, CT, USA, 2009.

Sample Availability: Samples of the compounds reported herein are available from the authors.

(C) 2015 by the authors; licensee MDPI, Basel, Switzerland. This article is an open access article distributed under the terms and conditions of the Creative Commons Attribution license (http://creativecommons.org/licenses/by/4.0/). 